\title{
The Fate of the Gallbladder in Patients Admitted to Bariatric Surgery
}

\author{
Bariatrik Cerrahiye Kabul Edilen Hastalarda Safra Kesesinin Kaderi \\ (1) Mehmet Celal Kızılkaya, (1) Serhan Yılmaz \\ University of Health Sciences Turkey, Kanuni Sultan Suleyman Training and Research Hospital, Clinic of General Surgery, Istanbul, Turkey
}

\begin{abstract}
Aim: Obesity has become a rapidly increasing public health problem all over the world. Obesity itself is a risk factor for cholelithiasis, and the fast weight loss period after bariatric surgery is a situation that increases this risk. The fact that both obesity and surgical treatment of obesity increases the formation of stones in the gall bladder has made it even defendible that cholecystectomy should be performed routinely during the bariatric surgery at one stage, even if there is no cholelithiasis. In this study, we aimed to evaluate our gallbladder approach in patients who were decided to undergo bariatric surgery in our center, together with the literature reviews.
\end{abstract}

Methods: In our study, the data of 185 patients who underwent bariatric surgery due to obesity in the University of Health Sciences Kanuni Sultan Suleyman the in Istanbul Training and Research Hospital Clinic of, Department of General Surgery, between 2018 and 2020 were retrospectively obtained. A total of 185 patients were included in the study. The patients were divided into group 1 (sleeve gastrectomy) and Group 2 (gastric bypass) according to their operation techniques.

Results: The average age was $36.43 \pm 9.52$, the ratio of women/ men was $151(81.6 \%) / 34(18.4 \%)$. Mean body mass index (BMI) was determined as 44.16 \pm 5.09 . In the postoperative period, gallstones were formed in 27 (14.6\%) patients, whereas gallstones were not detected in 158 (85.4\%) patients. There was no significant difference between the groups in terms of postoperative gallstone formation.

Conclusion: In the light of the literature and after our clinical experience, we do not require routine imaging of the gallbladder before bariatric surgery in asymptomatic patients, and we recommend performing concomitant cholecystectomy only in symptomatic patients.

Keywords: Obesity, bariatric surgery, cholelithiasis, cholecystectomy, gallstone
Öz

\begin{abstract}
Amaç: Obezite, tüm dünyada hızla artan bir toplum sağlığı problemi haline gelmiştir. Obezitenin kendisi safra kesesi taşı oluşumu için bir risk faktörü olup, bariatrik cerrahi sonrası hızlı kilo verme dönemi de bu riski artıran bir durumdur. Hem obezitenin hem de obezitenin cerrahi tedavisinin safra kesesinde taş oluşumunu artırması, bariatrik cerrahi sırasında kesede taş olmasa bile kolesistektominin de rutin olarak yapılması gerektiğini bir dönem savunulur hale getirmiştir. Biz bu çalışmamızda merkezimizde bariatrik cerrahi kararı verilen hastalarda safra kesesi yaklaşımımızı literatür değerlendirmeleri ile beraber ele almayı amaçladık.
\end{abstract}

Yöntemler: Çalışmamızda 2018-2020 yılları arasında İstanbul Kanuni Sultan Süleyman Eğitim ve Araştırma Hastanesi Genel Cerrahi Kliniği'nde obezite nedeni ile bariatrik cerrahi operasyonu geçiren toplan 185 hastanın bilgileri retrospektif olarak değerlendirildi. Çalışmaya toplam 185 hasta dahil edildi. Hastalar operasyon tekniklerine göre grup 1 (sleeve gastrektomi) ve grup 2 (gastrik bypass) olacak şekilde ayrıldı.

Bulgular: Yaş ortalaması 36,43 $\pm 9,52$ yıl, kadın/erkek oranı ise $151(\% 81,6) / 34(\% 18,4)$ idi. Ortalama vücut kitle indeksi

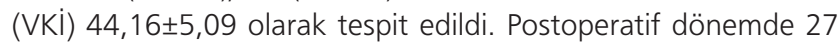
$(\% 14,6)$ hastada safra kesesi taşı oluşurken, $158(\% 85,4)$ hastada safra kesesinde taş tespit edilmedi. Gruplar arasında postoperatif safra kesesi taşı oluşumu açısından anlamlı fark yoktu.

Sonuç: Literatür ışığında ve klinik tecrübelerimiz sonrası, bariatrik cerrahi öncesi safra kesesi görüntülemesinin asemptomatik hastalarda rutin yapılmasını gerek görmemekte, sadece semptomatik hastalarda eşzamanlı kolesistektomi yapılmasını önermekteyiz.

Anahtar Sözcükler: Obezite, bariatrik cerrahi, safra kesesi taşı, kolesistektomi, safra taşı
Address for Correspondence/Yazışma Adresi: Mehmet Celal Kızılkaya, University of Health Sciences Turkey, Kanuni Sultan Suleyman Education and Research Hospital, Clinic of General Surgery, Istanbul, Turkey

E-mail: drmckizilkaya@gmail.com ORCID: orcid.org/0000-0001-8314-9908

Received/Geliş Tarihi: 11.12.2020 Accepted/Kabul Tarihi: 01.01.2021

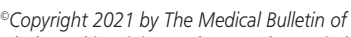
istanbul Haseki Training and Research Hospital The Medical Bulletin of Haseki published by Galenos Yayinevi. ${ }^{\top}$ Telif Hakkı 2021 istanbul Haseki Eğitim ve Araştırma Hastanesi Haseki Tıp Bülteni, Galenos Yayınevi tarafından yayınlanmıştır. 


\section{Introduction}

Obesity has become a rapidly increasing public health problem all over the world. This problem has serious consequences due to the comorbid diseases it brings. For this reason, many studies have been conducted on obesity treatment all over the world. Studies have shown that the gold standard in the fastest, permanent and long-term treatment of obesity is bariatric surgery (1). Bariatric surgical procedures such as Roux-en-Y gastric bypass (RYGB), laparoscopic sleeve gastrectomy (LSG), single anastomotic gastric bypass (OAGB), biliopancreatic diversion-duodenal switch (BPD-DS) and laparoscopic adjustable gastric band (LAGB) are the modern techniques used nowadays. It is a fact that bariatric surgery has benefits for the improvement of comorbid diseases (2).

In addition to all the benefits of these surgeries, there are also problems that may occur after surgery. One of these is the increased risk of gallstones formation, as stated in the literature (3). Obesity itself is a risk factor of cholelithiasis, and the period of rapid weight loss after bariatric surgery also increases this risk (4). The rate of cholelithiasis in the first year after bariatric surgery has been reported to be 35\% (5).

Rapid weight loss causes an increase in bile cholesterol concentration, the major metabolic counterpart of cholesterol, which is the main reason for the formation of gallstones $(6,7)$. Gallbladder hypomotility, increase in calcium secretion, impaired enterohepatic circulation of arachidonic acid derivatives, biliary mucin and bile salts also contribute to gallstone formation $(8,9)$. As a result, after bariatric surgery, patients are at risk of developing stone complications such as biliary colic, acute cholecystitis, acute pancreatitis, and gallstone migration.

The risk of gallstone formation is very high in patients who have a high body mass index (BMI) before bariatric surgery and will lose weight in a short time after surgery (10).

For these reasons, there is no consensus in the literature regarding the investigation of gallstones with bariatric pre-surgical imaging, how to approach the gallbladder in patients with asymptomatic gallstones and in symptomatic patients, and there are various meta-analyzes regarding those above.

In this study, we aimed to evaluate our gallbladder approach in patients who were decided to have bariatric surgery in our center, together with the literature reviews.

\section{Methods}

In our study, the data of 200 consecutive patients who underwent bariatric surgery due to obesity in the General Surgery Clinic of Istanbul Kanuni Sultan Suleyman Training and Research Hospital between 2018 and
2020 were retrospectively obtained. Ethics committee approval of the study was obtained from the local ethics committee with the number of KAEK-2020.12.220 on 10.12.2020. Patients who underwent bariatric surgery for obesity were included in the study. Those who had cholecystectomy before bariatric surgery, those who underwent concomitant cholecystectomy (CC) during bariatric surgery, those with concomittant gall stoness and those who did not attend their follow-up regularly were excluded from the study. Patients' age, gender, pre-operative $\mathrm{BMI}$, pre-operative comorbid diseases, preoperative hepatobiliary ultrasonography (USG) findings, which surgical procedure they underwent, postoperative BMI, postoperative complications, and ultrasound findings 6 months after surgery were recorded. The patients were divided into two groups according to the bariatric surgical procedure. The patients who underwent LSG were included in the first group, and the patients who had laparoscopic RYGB in the second.

\section{Statistical Analysis}

Frequency and percentage for categorical variables, mean and standard deviation values for continuous variables were given. The normality of the variables was checked with the Shapiro-Wilk test. Mann-Whitney U test was used for the analysis of continuous variables not distributed normally. Chi-square test was used for comparison of categorical variables. All analyzes were performed with the Social Sciences Statistics Package for Windows 22.0 (SPSS Inc., Chicago, Illinois, USA) and results with $p<0.05$ were considered significant.

\section{Results}

A total of 185 patients were included in the study. The average age was $36.43 \pm 9.52$ years and, the ratio of women/men was 151 (81.6\%)/34 (18.4\%). Mean BMI was determined as $44.16 \pm 5.09$. When comorbidities were evaluated, 116 (62.7\%) patients had comorbidity, while 69 (37.3\%) patients did not. There were no preoperative gallstones in any patient. The mean $\mathrm{BMI}$ at the postoperative 6 th month was found to be $32.30 \pm 3.98$ (Table 1). The patients were divided into group 1 (sleeve gastrectomy) and group 2 (gastric bypass) according to their operation techniques. There were 138 (74.6\%) patients in group 1, and $47(25.4 \%)$ patients in group 2. The mean age of the groups was $36.28 \pm 9.58$ and $36.87 \pm 9.44$ years, respectively, there was no significant difference between the groups in terms of mean age $(p=0.567)$. The female/male ratio was $120(87.0 \%) / 18$ $(13 \%)$ in group 1, and $31(66.0 \%) / 16(34.0 \%)$ in group 2. There was a significant difference in gender between the groups $(p=0.002)$. In group 1 , female gender was significantly higher. In group 1, 89 (64.5\%) patients had 
Table 1. Demographic data of patients

\begin{tabular}{|l|l|}
\hline Age & $36.43 \pm 9.52(20-60)$ \\
\hline Gender & $151(81.6 \%)$ \\
\hline \multicolumn{1}{|c|}{ Female } & $34(18.4 \%)$ \\
\hline Male & $44.16 \pm 5.09$ \\
\hline BMI & $116(62.7 \%)$ \\
\hline Comorbid disease & $69(37.3 \%)$ \\
\hline \multicolumn{1}{|c|}{ Yes } & $32.30 \pm 3.98$ \\
\hline No & $\begin{array}{l}\text { Sixth month BMI } \\
\text { Frequency and percentage values for categorical variables, mean and standard } \\
\text { deviation values for continuous variables are given. } \\
\text { BMI: Body mass index }\end{array}$ \\
\hline
\end{tabular}

\begin{tabular}{|c|c|c|c|}
\hline & $\begin{array}{l}\text { Group } 1 \\
(n=138)\end{array}$ & $\begin{array}{l}\text { Group } 2 \\
(n=47)\end{array}$ & $p$ \\
\hline Age & $36.28 \pm 9.58$ & $36.87 \pm 9.44$ & 0.567 \\
\hline \multicolumn{4}{|l|}{ Gender } \\
\hline Female & $120(87.0 \%)$ & $31(66.0 \%)$ & \multirow{2}{*}{0.002} \\
\hline Male & $18(13 \%)$ & $16(34.0 \%)$ & \\
\hline BMI & $45.31 \pm 4,77$ & $40.76 \pm 4.45$ & $<0.001$ \\
\hline \multicolumn{4}{|l|}{ Comorbid disease } \\
\hline Yes & $89(64.5 \%)$ & 27 (57.4\%) & \multirow{2}{*}{0.389} \\
\hline No & $46(35.5 \%)$ & $20(42.6 \%)$ & \\
\hline Sixth month BMI & $32.44 \pm 4.31$ & $31.91 \pm 2.78$ & 0.895 \\
\hline \multicolumn{4}{|l|}{ Cholelithiasis } \\
\hline Yes & $24(17.4 \%)$ & $3(6.4 \%)$ & \multirow{2}{*}{0.092} \\
\hline No & $114(82.6 \%)$ & $44(93.6 \%)$ & \\
\hline \multicolumn{4}{|c|}{$\begin{array}{l}\text { Frequency and percentage for categorical variables, mean and standard deviation } \\
\text { values for continuous variables are given. Chi-square and Mann-Whitney U tests } \\
\text { were used in group comparisons. P }<0.005 \text { was considered significant. BMI: Body } \\
\text { mass index }\end{array}$} \\
\hline
\end{tabular}

additional disease, while 46 (35.5\%) patients did not. While additional disease was detected in 27 (57.4\%) patients in Group 2, it was not detected in 20 (42.6\%) patients. There was no significant difference between the groups in terms of comorbidity $(p=0.389)$. The mean $\mathrm{BMI}$ of the groups were $45.31 \pm 4.77$ and $40.76 \pm 4.45$, respectively. BMI was significantly different between groups $(p<0.001)$. BMI was significantly higher in group 1. The mean $\mathrm{BMI}$ of the groups in the postoperative $6^{\text {th }}$ month was $32.44 \pm 4.31,31.91 \pm 2.78$, respectively. There was no significant difference between the groups in terms of $6^{\text {th }}$ month BMI $(p=0.895)$. In the postoperative period, gallstones were formed in 27 (14.6\%) patients, whereas gallstones were not detected in 158 (85.4\%) patients. There was no significant difference between the groups in terms of postoperative gallstone formation $(p=0.092)$ (Table 2).

\section{Discussion}

It is known that the risk of gallstone formation increases considerably after bariatric surgery, and its incidence varies between $10 \%$ and $38 \%$ (11). This also carries the risks of biliary complications.

Prophylactic cholecystectomy along with bariatric surgery prevents gallstone formation and stone-related complications. In addition, CC will reduce additional costs and hospitalization. However, simultaneous cholecystectomy is technically difficult during laparoscopic bariatric surgery due to, suboptimal port placement, visceral obesity, difficulty in accessing the gallbladder by the large liver, and prolonged surgery (12). In conclusion, while the place of prophylactic cholecystectomy in morbidly obese patients remains unclear, the timing of cholecystectomy in these patients remains a concern (13).

Gallstone migration becomes a difficult situation to manage in cases of BPD or gastric bypass (GB). Changes in anatomy prevent standard treatment with endoscopic retrograde choledochopancreaticography (13).

Many randomized studies have shown that the administration of ursodeoxycholic acid (UDCA) after bariatric surgery reduces gallstone formation and cholecystectomy rates after bariatric surgery (14-17). Sugerman et al. (18) showed that the use of UDCA (600 mg per day) for 6 moths after bariatric surgery reduces the formation of gallstones (cholelithiasis was detected in $2 \%$ of patients using UDCA and in 32\% of patients who did not). Especially with UDCA prophylaxis (for 6 months), the risk of postoperative biliary complications appears low, and CC can be avoided (13).

In our clinic, we did not start UDCA in our patients after surgery. In our series, gallstones were observed in $14.6 \%$ of the patients ( 27 patients) in the postoperative 6th month. Laparoscopic cholecystectomy was performed in 3 of these patients because they were symptomatic, and no complications were observed during and after the operation. These 3 patients were excluded as described previously.

Sakorafas et al. (19) and Patel et al. (20) in their studies, they reported that asymptomatic gallstones became symptomatic after bariatric surgery as less than $5 \%$. In the light of such studies, surgical treatment of asymptomatic gallstones after bariatric surgery is not routinely performed.

In a review study, routine gallbladder imaging before LSG, LAGB, RYGB operations and CC with surgery were not recommended in asymptomatic patients (4).

Studies in the literature report that performing CC together with bariatric surgery brings high morbidity and long hospitalization periods (21). The addition of cholecystectomy to bariatric surgery is associated with 
an increased risk of postoperative complications and an additional mean operative time of 32.84 minutes. Technically, the difficulty of accompanying cholecystectomy and bariatric surgery may increase the risk of complications $(22,23)$.

In our series, 10 patients underwent CC, and it did not cause any complications or prolonged hospitalization.

In a study, while the rate of patients with symptomatic bile mud or stones after RYGB was $8.7 \%$, this rate was reported as 3.8\% after LSG (24).

According to a meta-analysis, increases in complication rates such as anastomotic leakage and stricture formation were observed in patients who underwent RYGB+CC compared to the patient group who underwent RYGB alone (24). However, the same study, on the other hand, stated that bariatic surgery increased the risk of gallstone formation, and stated that controlled randomized largeseries studies are needed (24).

In one study, it was reported that the procedure with the lowest rate of cholecystectomy in the 10-year follow-up period after bariatric surgery was LAGB (6.5\%), followed by RYGB $(9.7 \%)$ and LSG (10.1\%), respectively (25).

In a meta-analysis, the risk of postoperative complications from cholecystectomy was lower than with post- or pre-bariatric surgery when performed with bariatric surgery. In addition, the risk of reoperation was lower for CC (13). In the same study, the authors stated that prophylactic cholecystectomy could be avoided because they reported that bariatric surgery patients had a low incidence of biliary complications, and CC increased the risk of postoperative complications and the mean operation time. However, they noted that if cholecystectomy is not performed during bariatric surgery, patients should be followed with special care for biliary complications. In the same study, it was stated that bariatric surgery and CC could be considered in patients with complaints about the gall bladder (13).

Although the vast majority of the stones are formed within 6 months after surgery, lenghtening of the followup period might have increased the number of patients with newly formed stones which may be interpreted as the weak point limiting the study.

In summary, we can mention the effects of bariatric surgery on other comorbid diseases and other undesirable effects such as kidney stones. LSG has a positive impact on hypothyroidism. Ruiz-Tovar et al. (26) found significant decrease in TSH level after LSG. The impact of LSG on hypertension is variable. Abelson et al. (27) also reported similar rates of 31\% remission at 5 and 7 year follow up respectively. Regarding type 2 diabetes mellitus, Golomb et al. (28) who demonstrated only $20 \%$ remission rate at
5 years. Abelson et al. (27) who found marked decline in the need of insulin therapy and mean number of oral hypoglycemic drugs in 132 diabetic patients undergoing LSG at 5 year follow-up. Another problem is kidney stones after bariatric surgery. From a review of a database of private insurance claims which contained 4639 patients who were matched to obese controls. Over a median follow-up of about 4 years, $7.65 \%$ of bariatric patients had a stone compared to $4.63 \%$ of obese controls (29).

\section{Conclusion}

In the light of the literature and after our clinical experience, we do not require routine imaging of the gallbladder before bariatric surgery in asymptomatic patients, and we recommend performing CC in symptomatic patients. We think that in symptomatic gallstones occurring after bariatric surgery, surgery does not bring about a serious increase in complications due to previous bariatric surgery.

\section{Authorship Contributions}

Concept: M.C.K., Design: M.C.K., Data Collection or Processing: M.C.K., Analysis or Interpretation: S.Y., Literature Search: M.C.K., Writing: M.C.K.

Conflict of Interest: No conflict of interest was declared by the authors.

Financial Disclosure: The authors declared that this study received no financial support.

\section{References}

1. Doulamis IP, Economopoulos KP. Transumbilical Roux-en-Y gastric bypass in morbidly obese patients: A systematic review. Int J Surg 2015;20:153-7.

2. Varela JE. Laparoscopic sleeve gastrectomy versus laparoscopic adjustable gastric banding for the treatment severe obesity in high risk patients. JSLS 2011;15:486-91.

3. Villegas L, Schneider B, Provost $D$, et al. Is routine cholecystectomy required during laparoscopic gastric bypass? Obes Surg 2004;14:206-11.

4. Leyva-Alvizo A, Arredondo-Saldaña G, Leal-Isla-Flores $V_{\text {, et al. }}$ Systematic review of management of gallbladder disease in patients undergoing minimally invasive bariatric surgery. Surg Obes Relat Dis 2020;16:158-64.

5. Fobi $M$, Lee $H$, Igwe $D$, et al. Prophylactic cholecystectomy with gastric bypass operation: incidence of gallbladder disease. Obes Surg 2002;12:350-3.

6. Njeze GE. Gallstones. Niger J Surg 2013;19:49-55.

7. Johnston DE, Kaplan MM. Pathogenesis and treatment of gallstones. N Engl J Med 1993;328:412-21.

8. Nagem R, Lázaro-da-Silva A. Cholecystolithiasis after gastric bypass: a clinical, biochemical, and ultrasonographic 3-year follow-up study. Obes Surg 2012;22:1594-9. 
9. Escalona A, Boza C, Muñoz R, et al. Routine preoperative ultrasonography and selective cholecystectomy in laparoscopic Roux-en-Y gastric bypass. Why not? Obes Surg 2008;18:4751.

10. Jonas E, Marsk R, Rasmussen F, Freedman J. Incidence of postoperative gallstone disease after antiobesity surgery: population-based study from Sweden. Surg Obes Relat Dis 2010;6:54-8.

11. Uy MC, Talingdan-Te MC, Espinosa WZ, Daez ML, Ong JP. Ursodeoxycholic acid in the prevention of gallstone formation after bariatric surgery: a meta-analysis. Obes Surg 2008;18:1532-8.

12. Iglézias Brandão de Oliveira $C$, Adami Chaim E, da Silva BB. Impact of rapid weight reduction on risk of cholelithiasis after bariatric surgery. Obes Surg 2003;13:625-8.

13. Tustumi F, Bernardo WM, Santo MA, Cecconello I. Cholecystectomy in Patients Submitted to Bariatric Procedure: A Systematic Review and Meta-analysis. Obes Surg 2018;28:3312-20.

14. Abdallah E, Emile SH, Elfeki H, et al. Role of ursodeoxycholic acid in the prevention of gallstone formation after laparoscopic sleeve gastrectomy. Surg Today 2017;47:844-50.

15. Coupaye M, Calabrese D, Sami O, Msika S, Ledoux S. Evaluation of incidence of cholelithiasis after bariatric surgery in subjects treated or not treated with ursodeoxycholic acid. Surg Obes Relat Dis 2017;13:681-85.

16. Coupaye M, Castel B, Sami O, Tuyeras G, Msika S, Ledoux S. Comparison of the incidence of cholelithiasis after sleeve gastrectomy and Roux-en-Y gastric bypass in obese patients: a prospective study. Surg Obes Relat Dis 2015;11:779-84.

17. Stokes CS, Gluud LL, Casper M, Lammert F. Ursodeoxycholic acid and diets higher in fat prevent gallbladder stones during weight loss: a meta-analysis of randomized controlled trials. Clin Gastroenterol Hepatol 2014;12:1090-100.

18. Sugerman HJ, Brewer WH, Shiffman ML, et al. A multicenter, placebo-controlled, randomized, double-blind, prospective trial of prophylactic ursodiol for the prevention of gallstone formation following gastric-bypass-induced rapid weight loss. Am J Surg 1995;169:91-6; discussion 96-7.

19. Sakorafas GH, Milingos D, Peros G. Asymptomatic cholelithiasis: is cholecystectomy really needed? A critical reappraisal 15 years after the introduction of laparoscopic cholecystectomy. Dig Dis Sci 2007;52:1313-25.
20. Patel JA, Patel NA, Piper GL, Smith DE 3rd, Malhotra G, Colella JJ. Perioperative management of cholelithiasis in patients presenting for laparoscopic Roux-en-Y gastric bypass: have we reached a consensus? Am Surg 2009;75:470-6; discussion 476.

21. Shiffman ML, Sugerman $H J$, Kellum JM, Brewer $W H_{t}$ Moore EW. Gallstone formation after rapid weight loss: a prospective study in patients undergoing gastric bypass surgery for treatment of morbid obesity. Am J Gastroenterol 1991;86:1000-5.

22. D'Hondt M, Sergeant G, Deylgat B, Devriendt D, Van Rooy F, Vansteenkiste F. Prophylactic cholecystectomy, a mandatory step in morbidly obese patients undergoing laparoscopic Roux-en-Y gastric bypass? J Gastrointest Surg 2011;15:15326.

23. Dakour-Aridi HN, El-Rayess HM, Abou-Abbass H, Abu-Gheida I, Habib RH, Safadi BY. Safety of concomitant cholecystectomy at the time of laparoscopic sleeve gastrectomy: analysis of the American College of Surgeons National Surgical Quality Improvement Program database. Surg Obes Relat Dis 2017;13:934-41.

24. Doulamis IP, Michalopoulos G, Boikou V, et al. Concomitant cholecystectomy during bariatric surgery: The jury is still out. Am J Surg 2019;218:401-10.

25. Altieri MS, Yang J, Nie L, Docimo S, Talamini M, Pryor AD. Incidence of cholecystectomy after bariatric surgery. Surg Obes Relat Dis 2018;14:992-6.

26. Ruiz-Tovar J, Boix E, Galindo I, et al. Evolution of subclinical hypothyroidism and its relation with glucose and triglycerides levels in morbidly obese patients after undergoing sleeve gastrectomy as bariatric procedure. Obes Surg 2014;24:7915.

27. Abelson JS, Afaneh C, Dolan P, Chartrand G, Dakin G, Pomp A. Laparoscopic Sleeve Gastrectomy: Co-morbidity Profiles and Intermediate-Term Outcomes. Obes Surg 2016;26:178893.

28. Golomb I, Ben David M, Glass A, Kolitz T, Keidar A. Long-term Metabolic Effects of Laparoscopic Sleeve Gastrectomy. JAMA Surg 2015;150:1051-7.

29. Matlaga BR, Shore AD, Magnuson T, Clark JM, Johns R, Makary MA. Effect of gastric bypass surgery on kidney stone disease. J Urol 2009;181:2573-7. 